\title{
APAKAH OPINI AUDIT MERUPAKAN SEBUAH GOOD NEWS? PENGUJIAN TEORI SIGNALING
}

\begin{abstract}
The objective of this study is to examine the effect of audit opinion and change in audit opinion on reporting delay. The auditor switch, the new accounting standard, unexpected earnings, leverage and profitability used as control variables. This study proposes hypotheses that the audit opinion which is better than the previous year will negatively affect reporting delay. Meanwhile, change in audit opinion better than the previous year will negatively affect on the reporting delay. Samples of this research is 170 manufacture firms listed in Indonesian Stock Exchange in year 2011-2012 that selected by using purposive sampling method. The technique of analysis used for examining the hypothesis is multiple regressions. The result of this research that audit opinion and change in audit opinion negatively affects reporting delay. Firms that receiving unqualified audit opinion and audit opinion better than the previous year gave a good news for investors so as to reduce the reporting delay.
\end{abstract}

Keywords: reporting delay, audit opinion, change in audit opinion, investors.

\section{PENDAHULUAN}

Peraturan mengenai ketepatan waktu pelaporan keuangan terdapat pada lampiran Keputusan Ketua Bapepam dan LK Nomor:Kep-346/BL/2011 dalam peraturan Bapepam Nomor X.K.2 menyatakan bahwa laporan keuangan tahunan harus disertai dengan laporan Akuntan dengan pendapat yang lazim dan disampaikan kepada Bapepam selambat-lambatnya pada akhir bulan ketiga setelah tanggal laporan keuangan tahunan. Peraturan ini diperketat dengan adanya sanksi administratif yang diberikan oleh Bapepam, jika perusahaan terlambat di dalam melakukan pelaporan keuangan.

Penundaan dalam pelaporan laporan keuangan perusahaan atau disebut dengan reporting delay merupakan suatu hal penting yang dapat mempengaruhi nilai dari laporan keuangan. Jika laporan keuangan dipublikasikan terlambat dari waktu yang ditentukan maka memiliki nilai buruk di mata investor. Menurut Subekti dan Widiyanti (2004), keterlambatan informasi akan menimbulkan reaksi negatif dari pelaku pasar modal. Laporan keuangan merupakan salah satu penghubung antara perusahaan dengan pihak luar. Givoly dan Palmon (1982) menyatakan bahwa reporting delay merupakan berita buruk (bad news) yang diterima oleh perusahaan. Oleh sebab itu, ada beberapa faktor yang dapat mempengaruhi reporting delay.

Laporan keuangan merupakan bentuk pertanggungjawaban perusahaan yang dibuat oleh manajemen kepada pemilik perusahaan. Selain itu, laporan keuangan dapat membantu investor dalam mengambil keputusan untuk berinvestasi. Sebelum laporan keuangan di publikasikan ke publik, laporan keuangan perlu untuk di audit terlebih dahulu oleh auditor. Pada peraturan yang dibuat oleh Badan Pengawas Pasar Modal mewajibkan laporan keuangan tahunan yang dilaporkan perusahaan go public harus lebih dahulu diaudit oleh akuntan yang terdaftar di Badan Pengawas Pasar Modal dan Lembaga Keuangan. 
Menurut Cullinan et al. (2012) perbedaan antara berbagai jenis perubahan opini dapat mempengaruhi ketepatan waktu pengungkapan laporan keuangan. Jadi, opini yang memiliki perubahan dari disclaimer ke wajar tanpa pengecualian maka akan lebih cepat untuk mempublikasikan laporan keuangan perusahaannya kepada publik, sedangkan jika opini audit mengalami perubahan dari wajar tanpa pengecualian ke wajar dengan pengecualian maka akan lebih lama untuk mempublikasikan laporan keuangan perusahaannya kepada publik. Menurut Begley dan Fischer (dalam Cullinan et al., 2012) mengukur perubahan laba dari satu tahun ketahun selanjutnya yaitu mengukur pendapatan dari satu periode ke periode selanjutnya. Oleh sebab itu, pada penelitian ini menggunakan perbandingan pendapatan antara satu tahun ketahun selanjutnya, begitu pula dengan opini audit membandingkan dari periode satu ke periode selanjutnya. Hasil penelitian mengenai reporting delay masih terbatas dilakukan dan menunjukkan temuan yang belum konsisten (misalnya Cullinan et al., 2012). Oleh karena itu diperlukan penelitian dalam konteks institusional yang berbeda dengan penelitian sebelumnya Indonesia. Lingkungan institusional Indonesia seperti two tiers corporate governance board systems, tingkat perlindungan investor yang lemah, praktek manajemen laba yang intensif, dan sistem code law mungkin dapat menyebabkan terbatasnya generalisasi temuan penelitian sebelumnya. Penelitian ini bertujuan untuk memberikan bukti empiris pengaruh opini audit dan perubahan opini audit terhadap kemungkinan terjadinya reporting delay dalam konteks Indonesia.

\section{KERANGKA PEMIKIRAN TEORITIS DAN PERUMUSAN HIPOTESIS}

Teori yang mendasari reporting delay yaitu teori sinyal (signaling theory) dan teori keagenan (agency theory). Dalam teori sinyal menurut Mutchler (1985) laporan audit diharapkan dapat berpotensi mempengaruhi harga saham terutama untuk dua alasan. Pertama, laporan audit mungkin berisi informasi yang mempengaruhi baik estimasi dari besarnya arus kas di masa mendatang dan/atau memberikan resiko atas pergerakan kas masa depan. Setiap informasi dapat menghasilkan perbaikan terhadap beberapa komponen dari laporan keuangan sehingga relevan dengan harga saham. Kedua, laporan audit dapat berisi informasi penting tentang kelangsungan hidup perusahaan, misalnya laporan audit going concern. Laporan ini harus selalu mencerminkan akses auditor terhadap informasi perusahaan seperti data perkiraan dan rencana pengelolaan serta keputusan pelaporan auditor juga mengungkapkan beberapa informasi pribadi perusahaan. Oleh karena itu, perusahaan yang menerima laporan audit yang buruk akan melakukan reporting delay sehingga mempengaruhi keputusan investor dalam berinvestasi.

Dalam kerangka teori keagenan menurut Jensen dan Meckling (1976) adalah teori yang menghubungkan antara agen (pengelola perusahaan) dengan prinsipal (pemilik perusahaan), yang terikat dalam kontrak Laporan keuangan merupakan salah satu informasi yang wajib dilaporkan oleh agen kepada prinsipal. Menurut Givoly dan Palmon (1982) laporan keuangan yang mengalami reporting delay merupakan berita buruk (bad news) bagi perusahaan. Oleh karena itu perusahaan diharapkan dapat menyajikan laporan keuangan secara tepat waktu.

\section{Pengaruh Opini Audit terhadap Reporting Delay}


Opini audit merupakan pendapat auditor mengenai laporan keuangan suatu perusahaan. Dimana auditor melakukan pemeriksaan secara independen terhadap laporan keuangan sehingga dapat dipertanggungjawabkan keandalan dari laporan keuangan perusahaan tersebut. Sesuai dengan pernyataan Hilmi dan Ali (2008) bahwa akuntan publik bertugas memberikan assurance terhadap laporan kewajaran laporan keuangan yang disusun dan diterbitkan oleh manajemen.

Menurut Wirakusuma (2004) perusahaan yang menerima opini wajar tanpa pengecualian dan opini wajar tanpa pengecualian dengan bahasa penjelasan cenderung lebih tepat waktu dibandingkan jika perusahaan menerima opini lain. Sesuai dengan Givoly dan Palmon (1982) bahwa berita buruk dari laporan keuangan berpengaruh positif terhadap penundaan pelaporan keuangan. Perusahaan yang menerima opini audit selain wajar tanpa pengecualian akan menunda pelaporan keuangan mereka dibandingkan dengan perusahaan yang menerima opini audit wajar tanpa pengecualian. Oleh karena itu, hipotesis yang dapat dikembangkan adalah:

\section{H1: Opini audit berpengaruh negatif terhadap reporting delay.}

\section{Pengaruh Perubahan Opini Audit Terhadap Reporting Delay}

Teori sinyal menyatakan bahwa ketepatan waktu penyampaian laporan keuangan merupakan kabar baik bagi investor (Cullinan et al, 2012). Salah satu yang menjadi ukuran kabar baik tersebut yaitu perubahan opini audit yang lebih baik dari tahun sebelumnya. Perubahan opini audit yang diteima oleh perusahaan dapat berbeda antar perusahaan. Perubahan opini tersebut dapat lebih buruk atau lebih baik dibandingkan dengan opini tahun sebelumnya. Menurut Cullinan et al. (2012) besarnya perubahan opini audit dapat berpengaruh terhadap ketepatan waktu pelaporan. Hal ini memungkinkan perusahaan untuk melakukan reporting delay ketika mereka menerima perubahan opini audit yang lebih buruk dari tahun sebelumnya. Berdasarkan uraian diatas maka hipotesis yang dapat dikembangkan adalah:

H2: Perubahan opini audit yang lebih baik dibandingkan dengan tahun sebelumnya berpengaruh negatif terhadap reporting delay.

\section{METODE PENELITIAN}

\section{Variabel Penelitian}

Variabel reporting delay diukur dengan menggunakan metodeyang dilakukan oleh Cullinan et al. (2012) yaitu selisih antara tanggal pelaporan keuangan tahun sebelumnya dengan tahun setelahnya berdasarkan tanggal penyampaian laporan keuangan tahunan auditan ke publik. Variabel opini audit diukur menggunakan variabel dummy, kode 1 untuk opini wajar tanpa pengecualian, dan kode 0 untuk opini selain wajar tanpa pengecualian. Variabel perubahan opini audit menggunakan variabel ordinal yaitu dengan memberikan nilai terhadap masing-masing opini audit, nilai 1 untuk opini wajar tanpa pengecualian, nilai 2 untuk opini wajar tanpa pengecualian dengan bahasa penjelasan, nilai 3 untuk opini wajar dengan pengecualian, nilai 4 untuk opini tidak wajar dan nilai 5 jika auditor tidak memberikan pendapatnya, selanjutnya diukur dengan menggunakan selisih antara opini audit yang diterima pada tahun sebelumya dengan opini audit yang 
diterima pada tahun berjalan. Penelitian ini juga menggunakan beberapa variabel kontrol yaitu pergantian auditor, standar akuntansi baru, pendapatan tidak terduga, leverage, dan profitabilitas. Variabel pergantian auditor diukur menggunakan variabel dummy, kode 1 untuk perusahaan yang melakukan pergantian auditor dan kode 0 untuk perusahaan yang tidak melakukan pergantian auditor. Variabel standar akuntansi baru diukur menggunakan variabel dummy, kode 1 untuk perusahaan yang telah mengadopsi IFRS dank kode 0 untuk perusahaan yang belum mengadopsi IFRS. Pada tahun 2012 perusahaan di Indonesia mulai mewajibkan untuk mengadopsi IFRS. Variabel pendapatan tidak terduga diukur menggunakan metode yang dilakukan oleh Cullinan et al. (2012) yaitu dengan menggunakan selisih laba bersih tahun berjalan dengan tahun sebelumnya dibagi dengan total aset tahun sebelumnya. Variabel leverage diukur menggunakan proksi debt to total asset. Rasio ini digunakan untuk mengukur seberapa besar asset perusahaan yang berasal dari utang perusahaan lain. Variabel profitabilitas diukur menggunakan ROA seperti penelitian yang dilakukan Saleh (2004). Rasio ini digunakan untuk mengetahui seberapa besar kemampuan perusahaan di dalam menghasilkan laba.

\section{Penentuan Sampel}

Sampel yang digunakan dalam penelitian ini diambil menggunakan metode purposive sampling dengan menggunakan beberapa kriteria yaitu: 1) Perusahaan manufaktur yang terdaftar di Bursa Efek Indonesia untuk periode tahun 2011-2012, 2) Menerbitkan laporan keuangan tahunan untuk periode 2011-2012,3) Melaporkan tanggal pelaporan laporan keuangan tahunan ke Bapepam untuk periode 2011-2012, 4) Menampilkan data mengenai opini audit, perubahan opini audit, pergantian auditor, standar akuntansi baru, pendapatan tidak terduga, leverage, dan profitabilitas yang berpengaruh terhadap reporting delay untuk periode 2011-2012. Dari kriteria penelitian tersebut diperoleh data sebanyak 212 perusahaan.

\section{Metode Analisis Data}

Pengujian hipotesis dilakukan dengan analisis multivariat dengan menggunakan analisis regresiberganda sebagai berikut:

\section{$D E L=\alpha 1+\beta 1$ AUDOPN $+\beta \neg 2$ OPNCHG $+\beta 3 A S+\beta 4 D N E W A C C+\beta 5 U E+\beta 6 L E V+\beta 7 P R O F+\varepsilon$}

\section{Dimana:}

$\begin{array}{lll}\text { a } & = & \text { Konstanta } \\ \text { DEL } & =\begin{array}{l}\text { Reporting Delay, yang diukur menggunakan selisih antara interval pelaporan laporan keuangan } \\ \text { berjalan dengan tahun fiskal berakhir terhadap interval pelaporan laporan keuangan tahun } \\ \text { sebelumnya dengan tahun fiskal berakhir }\end{array} \\ \text { AUDOPN }= & \text { Opini Audit } \\ \text { OPNCHG }= & \text { Perubahan Opini Audit } \\ \text { AS }= & \text { Pergantian Auditor } \\ \text { DNEWACC }= & \text { Standar Akuntansi Baru }\end{array}$




$\begin{array}{ll}\text { UE } & =\text { Pendapatan Tidak Terduga } \\ \text { LEV } & =\text { Leverage } \\ \text { PROF } & =\text { Profitabilitas } \\ \varepsilon & =\text { Error }\end{array}$

\section{HASIL PENELITIAN DAN PEMBAHASAN}

\section{Deskripsi Objek Penelitian}

Berdasarkan perhitungan menggunakan metode purpose sampling, maka diperoleh sampel sebanyak 75 perusahaan dengan kriteria sebagai berikut:

1. Perusahaan manufaktur yang terdaftar di Bursa Efek Indonesia untuk periode tahun 2011-2012.

2. Menerbitkan laporan keuangan tahunan untuk periode 2011-2012.

3. Melaporkan tanggal pelaporan laporan keuangan tahunan ke Bapepam untuk periode 2011-2012.

4. Menampilkan data mengenai opini audit, perubahan opini audit, pergantian auditor, standar akuntansi baru, pendapatan tidak terduga, leverage, dan profitabilitas yang berpengaruh terhadap reporting delay untuk periode 2011-2012.

Perusahaan-perusahaan sampel tersebut kemudian diklasifikasi berdasarkan lamanya waktu perusahaan dalam penyampaian laporan keuangan dibandingkan dengan tahun sebelumnya selama periode penelitian.

DariTabel 2 di dapat diketahui bahwa pada tahun 2011 dan 2012 perusahaan manufaktur yang melaporkan laporan keuangan mereka lebih cepat dari tahun sebelumnya untuk periode tahun 2011 dan 2012 masingmasing sebanyak 19 (22,35\%) perusahaan dan 66 (77,65\%) perusahaan, sedangkan perusahaan yang tidak mengalami perubahan di dalam melakukan pelaporan laporan keuangan tahunan dengan tahun sebelumnya pada tahun 2011 sebanyak 25 (29,41\%) dan untuuk tahun 2012 tidak ada perusahaan yang menyampaikan laporan keuangan mereka sama dengan tahun sebelumnya. Terdapat beberapa perusahaan yang melaporkan laporan keuangan mereka lebih lama dari tahun sebelumnya pada periode tahun 2011 dan 2012 masingmasing sebanyak 41 (48,24\%) perusahaan dan 19 (22,35\%) perusahaan. Hal ini menunjukkan bahwa pada tahun 2012 perusahaan manufaktur mengalami peningkatan dalam melaporkan laporan keuangan mereka dibandingkan dengan tahun sebelumnya. Tabel 3 mengelompokkan perusahaan yang menerima opini audit yaitu sebagai berikut:

Pada Tabel 3 perusahaan manufaktur yang menerima opini wajar tanpa pengecualian (unqualified opinion) sebanyak 66 (38,82\%) perusahaan dan perusahaan yang menerima opini audit diluar opini wajar tanpa pengecualian (non unqualified opinion) sebanyak 104 (61,18\%) perusahaan. Hal ini menunjukkan bahwa perusahaan manufaktur yang menjadi sampel dalam penelitian ini rata-rata menerima opini audit diluat dari opini audit wajar tanpa pengecualian. Perubahan opini audit untuk dapat dikelompokkan sebagai berikut:

Pada Tabel 4 sampel yang mengalami perubahan opini audit positif sebanyak 33 (19,41\%) perusahaan. Terdapat beberapa perusahaan yang tidak mengalami perubahan yaitu sebanyak 97 (57,06\%) perusahaan. Arah perubahan negatif terjadi pada 40 (23,53\%) perusahaan manufaktur yang menjadi sampel penelitian. Hal ini 
menunjukkan bahwa rata-rata perusahaan manufaktur dalam penelitian ini tidak mengalami perubahan opini audit. Perusahaan-perusahaan yang menjadi obyek dalam penelitian ini juga dikelompokkan berdasarkan pergantian auditor yang tersaji dalam Tabel 5.

Tabel 5 menunjukkan bahwa perusahaan yang melakukan pergantian auditor selama tahun penelitian sebanyak 78 (45,88\%) perusahaan dan yang tidak melakukan pergantian auditor selama tahun penelitian sebanyak $92(54,12 \%)$ perusahaan. hal ini menunjukkan bahwa perusahaan manufaktur rata-rata tidak mengalami pergantian auditor.

Sampel juga dikelompokkan berdasarkan penggunaan standar akuntansi baru yang telah mengadopsi standar IFRS dan belum mengadopsi standar IFRS yaitu dapat dijelaskan dalam Tabel 6.

Tabel 6 menjelaskan bahwa terdapat 85 (50\%) perusahaan yang telah mengadopsi IFRS dan terdapat 85 (50\%) perusahaan yang belum mengadopsi IFRS. Hal ini dikarenakan pada tahun 2012 perusahaan diwajibkan untuk mengadopsi secara penuh IFRS.

\section{Analisis Data}

Pengujian statistik deskriptif dilakukan untuk mengetahui nilai rata-rata (mean), maksimum, minimum dan deviasi standar dari penelitian ini. Dengan menggunakan statistik deskriptif data dapat tersaji dengan ringkas sehingga dapat dengan mudah untuk melihat ukuran persebaran datanya normal atau tidak. Untuk lebih jelasnya statistik deskriptif dari masing-masing variabel yang digunakan dalam penelitian ini ditunjukkan pada Tabel 7.

\section{Hasil Uji Asumsi Klasik}

Pengujian hipotesis yang digunakan pada penelitian yaitu model regresi berganda. Pada penggunaan model regresi OLS ini terlebih dahulu harus memenuhi uji asumsi klasik. Untuk lebih jelasnya dapat dilihat pada Tabel 8.sebagai berikut:

\section{Hasil Uji Asumsi Klasik}

Uji Normalitas: Berdasarkan Tabel 8 dapat diketahui bahwa nilai signifikan dari uji One-Sample Kolmogorov Smirnov adalah 0,062 (sig.>0,05) yang menyatakan bahwa distribusi data pada penelitian ini adalah normal.

Uji Multikolinieritas: Berdasarkan Tabel 8 dapat diketahui bahwa nilai VIF menunjukkan < 10, yang menyatakan bahwa masing-masing dari variabel bebas tidak memiliki hubungan. Dengan demikian hasil dari pengujian ini menunjukkan bahwa Uji Multikolinieritas terpenuhi.

Uji Heteroskedastistias: Tabel 8 menjelaskan bahwa hasil dari Uji Glejser menunjukkan seluruh nilai signifikansi dari masing-masing variabel bebas lebih dari 0,05 (sig.>0,05), sehingga data dalam penelitian ini tidak terjadi heteroskedastisitas.

Uji Autokorelasi: Berdasarkan Tabel 8 menjelaskan nilai Durbin-Watson pada penelitian ini sebesar 1,850. Nilai tersebut dibandingkan dengan tabel Durbin-Watson dengan tingkat ignifikansi 5\%. Jumlah sampel penelitian selama 2 periode sebanyak 170 perusahaan dengan jumlah variabel independen dan kontrol 
sebanyak $7(\mathrm{k}=7$ ) sehingga nilai $\mathrm{dl}=1,664$; $\mathrm{du}=1,835$; 4- $\mathrm{du}=2,265$; dan 4- $\mathrm{dl}=2,336$. Berdasarkan data diatas bahwa nilai Durbin-Watson pada penelitian ini berada diantara du dan 4-du $(1,835<1,850<2,265)$, sehingga data tersebut tidak terjadi autokorelasi.

\section{HASIL PENGUJIAN HIPOTESIS}

\section{Opini Audit}

Pada penelitian ini perusahaan yang menerima opini audit wajar tanpa pengecualian sebanyak 66 $(38,82 \%)$ perusahaan dan perusahaan yang menerima opini audit selain wajar tanpa pengecualian sebanyak $104(61,18 \%)$ perusahaan. Nilai t pada variabel opini audit (AUDOPN) memiliki nilai sebesar -2,846 dengan sigifikansi sebesar 0,005 dan nilai beta sebesar -0,207. Hal ini menunjukkan bahwa nilai signifikansi 0,005 $<0,05$, maka variabel AUDOPN berpengaruh negatif terhadap variabel reporting delay (DEL) sebesar 20,7\%. Dengan demikian, hasil penelitian ini mendukung hipotesis satu $(\mathrm{H} 1)$, sehingga perusahaan yang menerima opini audit wajar tanpa pengecualian akan lebih cepat melaporkan laporan keuangan mereka ke publik. Hasil penelitian ini sesuai dengan penelitian yang dilakukan oleh Wirakusuma (2004) yang menunjukkan bahwa opini audit memiliki pengaruh terhadap rentang waktu pengumuman laporan keuangan auditan ke publik. Oleh karena itu, opini audit memiliki pengaruh negatif terhadap reporting delay. Pada penelitian yang dilakukan oleh Cullinan et, al. (2012) opini audit juga memiliki pengaruh terhadap reporting delay.

Sesuai dengan teori keagenan, perusahaan yang menerima opini audit wajar tanpa pengecualian tidak melakukan reporting delay dalam melaporkan laporan keuangan mereka. Semakin baik opini audit yang diterima perusahaan maka perusahaan akan semakin cepat melaporkannya ke publik. Oleh karena itu, perusahaan cenderung lebih cepat melaporkan laporan keuangan mereka dibandingkan dengan perusahaan yang menerima opini audit lain. Hal ini menunjukkan bahwa perusahaan memberikan kabar baik (good news) terhadap investor. Kabar baik tersebut juga merupakan sinyal positif untuk para investor dalam mengambil keputusan investasi mereka.

\section{Perubahan Opini Audit}

Pada variabel perubahan opini audit terdapat beberapa perusahaan yang mengalami perubahan positif yaitu sebanyak 33 (19,41\%) perusahaan, tidak mengalami perubahan opini audit sebanyak 97 (57,06\%) perusahaan, dan mengalami perubahan negatif sebanyak $40(23,53 \%)$ perusahaan. Variabel perubahan opini audit (OPNCHG) memiliki nilai t sebesar -2,589 dengan signifikansi sebesar 0,011 dan nilai beta sebesar 0,190. Hal ini menunjukkan bahwa nilai signifikansi 0,011<0,05, maka variabel OPNCHG berpengaruh negatif terhadap variabel reporting delay (DEL) sebesar 19\%. Dengan demikian, hasil penelitian ini mendukung hipotesis dua $(\mathrm{H} 2)$, sehingga perusahaan yang mengalami perubahan positif akan lebih cepat melaporkan laporan keuangan mereka. Hasil penelitian ini sesuai dengan penelitian yang dilakukan oleh Cullinan et al. (2012) yang menyatakan bahwa perubahan opini audit memiliki pengaruh yang signifikan terhadap reporting delay.

Perubahan opini audit memiliki pengaruh negatif terhadap reporting delay yaitu perusahaan yang 
menerima opini audit lebih baik dari tahun sebelumnya cenderung untuk melaporkan laporan keuangan tahunan mereka lebih cepat dibandingkan dengan perusahaan yang mengalami penurunan dalam menerima opini audit. Hal ini menunjukkan bahwa perusahaan yang menerima opini audit lebih baik dari tahun sebelumnya memberikan sinyal positif atau kabar baik (good news) terhadap para investor.

\section{SIMPULAN}

Penelitian ini bertujuan untuk menganalisis dan memperoleh bukti adanya pengaruh opini audit dan perubahan opini audit terhadap kemungkinan terjadinya reporting delay pada perusahaan manufaktur yang terdaftar di Bursa Efek Indonesia dengan menggunakan sampel sebanyak 85 perusahaan untuk dua periode yaitu tahun 2011 dan 2012 sehingga jumlah sampel penelitian ini sebanyak 85 × $2=170$ sampel. Berdasarkan hasil analisis data dan pembahasan yang telah dijelaskan pada bab IV dapat diambil kesimpulan sebagai berikut:

1. Opini audit (AUDOPN) berpengaruh negatif terhadap variabel reporting delay. Perusahaan yang menerima opini audit wajar tanpa pengecualian dan opini selain wajar tanpa pengecualian memiliki pengaruh terhadap reporting delay.

2. Perubahan opini audit (OPNCHG) berpengaruh negatif terhadap variabel reporting delay. Perusahaan yang mengalami perubahan opini audit yang lebih baik dan lebih buruk dari pada tahun sebelumnya memiliki pengaruh terhadap reporting delay.

Hasil dari penelitian ini menunjukkan bahwa perusahaan manufaktur pada periode 2011 dan 2012 yang menerima opini audit wajar tanpa pengecualian dan perubahan opini audit yang lebih baik dari tahun sebelumnya berpengaruh negatif terhadap reporting delay. Oleh karena itu, perusahaan memberikan sinyal positif atau kabar baik (good news) kepada para investor. Hal ini dapat membantu investor dalam mengambil keputusan investasi mereka.

Keterbatasan dalam penelitian ini yaitu penggunaan variabel independen dan variabel kontrol untuk menganalisis faktor-faktor yang berpengaruh terhadap terjadinya reporting delay terbatas pada opini audit, perubahan opini audit, pergantian auditor, standar akuntansi baru, pendapatan tidak terduga, leverage, dan profitabilitas. Karena variabel tersebut hanya mampu menjelaskan variabel reporting delay sebesar $28,6 \%$. Pada penggunaan periode waktu penelitian yang digunakan dalam penelitian ini memiliki periode waktu yang terbatas yaitu selama 2 tahun dengan sampel penelitian sebanyak 170 perusahaan dikarenakan keterbatasan informasi yang diterima oleh peneliti.

Berdasarkan kesimpulan dan keterbatasan penelitian, maka peneliti memberikan beberapa saran untuk penelitian yang akan datang yaitu:

1. Menambah variabel penelitian yang diduga dapat berpengaruh secara signifikan terhadap reporting delay.

2. Memperpanjang periode waktu penelitian sehingga hasil yang diperoleh dapat lebih menggambarkan kondisi sebenarnya dalam jangka panjang. 


\section{DAFTAR PUSTAKA}

Badan Pengawas Pasar Modal Dan Lembaga Keuangan. 2009. Annual Report, Jakarta

Carslaw, C. A. P. N., dan Kaplan, S.E. 1991. "An Examination Of Audit Delay: Further Evidence from New Zealand". Accounting and Business Research. Vol 22. No 85. pp 21-32

Cullinan, Charles P., Wang, F., Yang B., dan Zhang, J. 2012. "Audit Opinion Improvement And The Timing Of Disclosure". Advances In Accounting, Incorporating Advances In International Accounting. Vol 28. pp: 333-343

Givoly, D. and Palmon, D. 1982. "Timeliness Of Annual Earnings Announcements: Some Empirical Evidence".

The Accounting Review. Vol 57. No 3. pp: 486-508

Hilmi, Utari dan Ali, Syaiful. 2008. "Analisis Faktor-Faktor Yang Mempengaruhi Ketepatan Waktu Penyampaian Laporan Keuangan (Studi Empiris Pada Perusahaan-Perusahaan Yang Terdaftar Di BEJ)". Simposium Nasional Akuntansi XI

Ikatan Akuntan Indonesia. 2012. Standar Akuntansi Keuangan. Penerbit Salemba Empat. Jakarta

Jensen, M. C. dan Meckling, W. H. 1976. "Theory of Firm: Managerial Behaviour, Agency Costs and Ownership Structure". Journal of Financial Economics. Vol 3. pp: 305-360

Keputusan Ketua Bapepam No: Kep- 86/BL/2011

-------. No: Kep-346/BL/2011

Ksa, Agrianti. 2003.“Faktor-Faktor Yang Menentukan Kepatuhan Perusahaan Public Terhadap Regulasi Informasi Di Indonesia". Simposium Nasional Akuntansi VI

Mulyadi. 2002. Auditing. Edisi Keenam. Jakarta: Salemba Empat

Mutchler, J. (1985). "A multivariate analysis of the auditor's going-concern opinion decision". Journal of Accounting Research 23:2, 668-682.

Saleh, Rachmaf. 2004. "Studi Empiris Ketepatan Waktu Pelaporan Keuangan Perusahaan Manufaktur Di Bursa Efek Jakarta". Simposium Nasional Akuntansi VII. h. 897-910

Samsul, Mohamad. 2006. Pasar Modal dan Manajemen Portofolio. Erlangga. Jakarta

Spence, M. (1973). “Job market signaling”. Quarterly Journal of Economics, 87(3), 355-374.

Subekti, Imam dan Widiyanti, Novi Wulandari. 2004. “Faktor-Faktor yang Berpengaruh Terhadap Audit Delay Di Indonesia", Simposium Nasional Akuntansi VII. h. 991-1002

Whittered, G.P.1980. "Audit Qualification And The Timeliness Of Coorporate Annual Reports". The Accouting Review. Vol 55. No 4. pp: 563-577

Wirakusuma, Made Gede. 2004. “Faktor-faktor Yang Mempengaruhi Rentang Waktu Penyajian Laporan Keuangan ke Publik (Studi Empiris Mengenai Keberatan Divisi Internal Audit Pada PerusahaanPerusahaan Yang Terdaftar Di Bursa Efek Jakarta)". Simposium Nasional Akuntansi VII. h. 1202-1222

www.bapepam.go.id diakses 21 September 2013

www.idx.co.id diakses tanggal 16 Januari 2014 


\section{LAMPIRAN}

Tabel 2

Distribusi Lamanya Waktu Perusahaan dalam Penyampaian Laporan Keuangan Dibandingkan dengan Tahun Sebelumnya selama Periode Penelitian

\begin{tabular}{lcccc}
\hline \multirow{2}{*}{ Reporting Delay Perusahaan } & \multicolumn{4}{c}{ Periode } \\
\cline { 2 - 5 } & \multicolumn{3}{c}{2011} & \multicolumn{2}{c}{2012} \\
\cline { 2 - 5 } & Jumlah & Persentase & Jumlah & Persentase \\
\hline Lebih cepat dari tahun sebelumya & 19 & $22,35 \%$ & 66 & $77,65 \%$ \\
\hline Sama dengan tahun sebelumnya & 25 & $29,41 \%$ & 0 & $0 \%$ \\
\hline Lebih lama dari tahun sebelumnya & 41 & $48,24 \%$ & 19 & $22,35 \%$ \\
\hline & $\mathbf{1 0 6}$ & $\mathbf{1 0 0}$ & $\mathbf{1 0 6}$ & $\mathbf{1 0 0 \%}$ \\
\hline
\end{tabular}

Sumber: Data sekunder yang diolah, 2014

Tabel 3

Opini Audit

\begin{tabular}{ccc}
\hline Opini Audit & Jumlah & Presentase \\
\hline Unqualified Opinion & 66 & $38,82 \%$ \\
Non Unqualified Opinion & 104 & $61,18 \%$ \\
\hline & 170 & $100,00 \%$
\end{tabular}

Sumber: Data sekunder yang telah diolah, 2014

Tabel 4

Perubahan Opini Audit

\begin{tabular}{ccc}
\hline Perubahan Opini Audit & Jumlah & Presentase \\
\hline Perubahan Positif & 33 & $19,41 \%$ \\
Tidak ada Perubahan & 97 & $57,06 \%$ \\
Perubahan Negatif & 40 & $23,53 \%$ \\
\hline & 170 & $100,00 \%$
\end{tabular}

Sumber: Data sekunder yang telah diolah, 2014 
Tabel 5

Pergantian Auditor

\begin{tabular}{ccc}
\hline Pergantian Auditor & Jumlah & Presentase \\
\hline Ada Pergantian & 78 & $45,88 \%$ \\
Tidak Ada Pergantian & 92 & $54,12 \%$ \\
\hline & 170 & $100,00 \%$ \\
\hline
\end{tabular}

Sumber: Data sekunder yang telah diolah, 2014

Tabel 6

Standar Akuntansi Baru

\begin{tabular}{ccc}
\hline Standar Akuntansi Baru & Jumlah & Presentase \\
\hline Sebelum Adopsi IFRS & 85 & $50,00 \%$ \\
Setelah Adopsi IFRS & 85 & $50,00 \%$ \\
\hline & 170 & $100,00 \%$ \\
\hline
\end{tabular}

Sumber: Data sekunder yang telah diolah, 2014

Tabel 7

Statistik Deskriptif

\begin{tabular}{lccrrr}
\hline & N & Minimum & Maksimum & Rata-rata & \multicolumn{1}{c}{$\begin{array}{c}\text { Deviasi } \\
\text { Standar }\end{array}$} \\
\hline DEL & 170 & $-50,00$ & 64,00 & $-1,16$ & 11,81 \\
UE & 170 & $-0,36$ & 0,56 & 0,02 & 0,10 \\
LEV & 170 & 0,10 & 3,08 & 0,56 & 0,54 \\
PROF & 170 & $-0,16$ & 0,42 & 0,08 & 0,10 \\
\hline
\end{tabular}

Valid N (listwise) $\quad 170$

Sumber: Data sekunder yang telah diolah, 2014

Tabel 8

Hasil Uji Asumsi Klasik dan Uji Regresi Berganda

\begin{tabular}{|c|c|c|c|c|c|}
\hline Variabel & $\begin{array}{c}\text { Nilai } \\
\text { Koefisien }\end{array}$ & t-value & Sig. & VIF & Glejser \\
\hline AUDOPN & $-0,207$ & $-2,846$ & 0,010 & 1,252 & 0,402 \\
\hline OPNCHG & 0,190 & $-2,589$ & 0,005 & 1,270 & 0,313 \\
\hline AS & $-0,197$ & 2,937 & 0,011 & 1,068 & 0,584 \\
\hline DNewacc & $-0,115$ & $-1,695$ & 0,004 & 1,080 & 0,972 \\
\hline UE & 0,044 & 0,617 & 0,092 & 1,199 & 0,073 \\
\hline LEV & 0,295 & 4,352 & 0,538 & 1,085 & 0,090 \\
\hline PROF & 0,118 & 1,624 & 0,000 & 1,256 & 0,757 \\
\hline \multicolumn{6}{|l|}{1,850} \\
\hline $\mathrm{R}^{2}(\%)$ & $31,5 \%$ & & & & \\
\hline Adjusted $R^{2}(\%)$ & $28,6 \%$ & & & & \\
\hline \multicolumn{6}{|c|}{10,653 dan sig. 0,000} \\
\hline One Sample K-S Test & 1,319 dan si & 062 & & & \\
\hline
\end{tabular}

Sumber: Data sekunder yang diolah, 2014 